\title{
Jurnal Riset Ekonomi dan Bisnis
}

http://journals.usm.ac.id/index.php/jreb

\section{MEMBANGUN KINERJA MELALUI BUDAYA ORGANISASI DAN ROTASI PEGAWAI DENGAN MOTIVASI KERJA SEBAGAI VARIABEL MEDIASI}

\author{
Sularwan ${ }^{1)}$; Djoko Santoso ${ }^{2)}$ \\ $\underline{\text { larwan@gmail.com }}^{\text {1)}}$; djoko_hw@usm.ac.id
}

Magister Manajemen, Universitas Semarang, Semarang, Indonesia

\section{Info Artikel}

Sejarah Artikel:

Diterima :7 april 2020

Disetujui : 12 Mei 2020

Dipublikasikan : 15

Agustus 2020

Keywords:

employee performance;

organizational culture;

Employees ' rotation; work

motivation.

\begin{abstract}
Abstrak
Penelitian ini bertujuan untuk menganalisis pengaruh budaya organisasi dan rotasi pegawai terhadap kinerja pegawai dengan motivasi kerja sebagai variabel mediasi (Studi empiris pada KPPBC TMP Tanjung Emas). Sampel dalam penelitian ini adalah 70 pegawai yang didapatkan dengan teknik purposive sampling. Alat analisis yang digunakan dalam penelitian ini adalah SPSS. Teknik analisis data dalam penelitian ini menggunakan teknik analisis jalur. Hasil penelitian menunjukkan bahwa budaya organisasi dan rotasi pegawai mempengaruhi kinerja pegawai pada KPPBC TMP Tanjung Emas secara langsung. Motivasi kerja terbukti sebagai variabel mediasi antara budaya organisasi dan kinerja pegawai.
\end{abstract}

\section{BUILDING PERFORMANCE THROUGH AN ORGANIZATIONAL CULTURE AND EMPLOYEE ROTATION WITH WORK MOTIVATION AS A MEDIATION VARIABLES}

\begin{abstract}
This study aims to analyze the influence of organizational culture and employee rotation on employee performance with work motivation as a mediating variable (Empirical Study on KPPBC TMP Tanjung Emas). The sample in this study was 70 employees obtained by purposive sampling technique. The analytical tool used in this study is SPSS. Data analysis techniques in this study used path analysis techniques. The results showed that organizational culture and employee rotation directly affect employee performance at the KPPBC TMP Tanjung Emas. Work motivation is proven as a mediating variable between organizational culture and employee performance.Abstrak Bahasa Inggris
\end{abstract}




\section{PENDAHULUAN}

Sumber daya manusia merupakan arti penting dari suatu realita bahwa setiap individu manusia merupakan elemen yang paling utama dalam suatu organisasi. Sumber daya terpenting suatu perusahaan atau organisasi adalah sumber daya manusia yaitu orang yang telah memberikan tenaga, bakat, kreatifitas dan usaha mereka kepada organisasi. Oleh karena itu, kemajuan suatu perusahaan dapat di tentukan dari sumber daya manusia yang mampu menampilkan kinerja terbaik dari setiap individu.

Semua potensi yang dimiliki manusia seperti keterampilan, motivasi, dan kecerdasan sangat berpengaruh terhadap upaya organisasi dalam mencapai tujuan. Perilaku manusia yang beranekaragam karakteristik dan perilakunya membuat pengelolaan sumber daya manusia tidak berjalan dengan mudah. Masalah sumber daya manusia menjadi sebuah tantangan bagi manajemen, karena keberhasilan perusahaan atau organisasi tergantung dari kualitas sumber daya manusia yang dimiliki/ dipekerjakan, tidak terkecuali di Kantor Pengawasan dan Pelayanan Bea dan Cukai Tipe Madya Pabean Tanjung Emas (KPPBC TMP Tanjung Emas).

Kantor Pengawasan dan Pelayanan Bea dan Cukai Tipe Madya Pabean Tanjung Emas merupakan instansi vertikal Direktorat Jenderal Bea dan Cukai, Kementerian Keuangan yang melayani masyarakat di bidang kepabeanan dan cukai. Tugas dan fungsi utamanya berkaitan erat dengan pengelolaan keuangan negara khususnya penerimaan negara, antara lain memungut bea masuk berikut pajak dalam rangka impor (PPN Impor, PPh Pasal 22, PPnBM), bea keluar, cukai, dan mengawasi kegiatan ekspor dan impor serta masuknya barang larangan dan pembatasan.

Untuk mendukung pelaksanaan tugas dan fungsinya dalam upaya mencapai tujuan organisasi, KPPBC TMP Tanjung Emas menerapkan Nilai-Nilai Kementerian Keuangan sebagaimana diatur dalam Peraturan Menteri Keuangan Republik Indonesia Nomor 190/PMK.01/2018 tentang Kode Etik dan Kode Perilaku Pegawai Negeri Sipil di Lingkungan Kementerian Keuangan dan Sikap Dasar Pegawai DJBC yang diatur dalam Keputusan Direktur Jenderal Bea dan Cukai Nomor KEP-664/BC/2017 Tentang Sikap Dasar Pegawai Direktorat Jenderal Bea Dan Cukai. Nilai-Nilai Kementerian Keuangan terdiri dari Integritas, Pelayanan, Sinergi, Profesional dan Kesempurnaan. Sedangkan sikap dasar yang harus dimiliki oleh pegawai bea dan cukai yaitu Jujur, Korsa, Loyal, Inisiatif dan Korektif (KLIK JUJUR).

Data capaian kinerja pegawai KPPBC TMP Tanjung Emas menunjukkan adanya fenomena penurunan capaian kinerja pegawai yang terlihat dari rata-rata hasil penilaian kinerja pegawai pada tahun 2017 dan 2018. Sejumlah 213 pegawai (94\%) dari 227 pegawai, yang terdiri dari 18 jenis jabatan mengalami penurunan capaian kinerja. Penurunan kinerja pegawai ini tidak terlepas dari beberapa faktor yang mempengaruhi diantaranya budaya oganisasi, rotasi pegawai dan motivasi kerja.

Penelitian terdahulu telah membuktikan pengaruh budaya organisasi dan rotasi pegawai terhadap motivasi kerja dan kinerja pegawai. Penelitian yang menguji pengaruh antara budaya terhadap kinerja karyawan dilakukan oleh Fatmawati (2012) dan Tharig Kemal (2014) yang menyatakan bahwa budaya organisasi berpengaruh terhadap kinerja pegawai. Penelitian yang dilakukan Fatmawati (2012) dan Nur Aini (2015) menunjukkan bahwa rotasi kerja berpengaruh terhadap kinerja pegawai dan motivasi kerja.

Penelitian tentang pengaruh budaya organisasi dan rotasi pegawai terhadap kinerja pegawai dengan motivasi kerja sebagai variabel mediasi sudah pernah ada, namun di KPPBC TMP Tanjung Emas baru kali ini di lakukan, dari penulusuran penelitian sebelumnya yang mengangkat tentang kinerja pegawai masih ditemukan adanya research gap, yang meliputi perbedaan hasil diantara peneliti dan keterbatasan penelitian sebelumnya, maka penelitian ini masih urgen untuk dilakukan. 


\section{TELAAH PUSTAKA}

\section{Pengaruh Budaya Organisasi terhadap Kinerja Pegawai Kerja}

Budaya organisasi menurut Hunt sebagaimana dirujuk oleh Irvan (2008), budaya organisasi adalah sistem yang dipercayai dan nilai yang dikembangkan oleh organisasi, sehingga hal itu menuntun perilaku dari anggota organisasi itu sendiri. Penelitian yang menguji pengaruh antara budaya terhadap kinerja karyawan dilakukan oleh Fatmawati (2012) dan Tharig Kemal (2014) yang menyatakan bahwa budaya organisasi berpengaruh terhadap kinerja pegawai. Berdasarkan uraian tersebut, dalam penelitian ini hipotesis dirumuskan sebagai berikut:H1: Ada pengaruh budaya organisasi terhadap kinerja pegawai.

\section{Pengaruh Rotasi Pegawai terhadap Kinerja Pegawai}

Menurut Robbins (2006) bahwa kekuatan dari rotasi pekerjaan adalah mampu mengurangi kebosanan dan meningkatkan motivasi melalui penganekaragaman kegiatan karyawan. Rotasi memiliki peranan penting dalam sistem penyelenggaraan kepegawaian dari sebuah organisasi. Penelitian yang dilakukan Fatmawati (2012) dan Nur Aini (2015) menunjukkan bahwa rotasi kerja berpengaruh terhadap kinerja pegawai. Berdasarkan uraian tersebut, dalam penelitian ini hipotesis dirumuskan sebagai berikut: $\mathrm{H} 2$ : Ada pengaruh rotasi pegawai terhadap kinerja pegawai.

\section{Pengaruh Budaya Organisasi terhadap Motivasi Kerja}

Budaya organisasi merupakan falsafah, ideologi, nilai-nilai, anggapan, keyakinan, harapan, sikap dan norma-norma yang dimiliki secara bersama serta mengikat dalam suatu komunitas tertentu (Robbins, 2006). Selanjutnya dikemukakan secara spesifik budaya dalam organisasi akan ditentukan oleh kerja sama tim, kepemimpinan, karakteristik organisasi dan proses administrasi yang berlaku. Penelitian yang dilakukan Fatmawati (2012) dan Hormati (2016) menunjukkan bahwa budaya organisasi berpengaruh terhadap motivasi kerja. Berdasarkan uraian tersebut, dalam penelitian ini hipotesis dirumuskan sebagai berikut: H3: Ada pengaruh budaya organisasi terhadap motivasi kerja.

\section{Pengaruh Rotasi Kerja terhadap Motivasi Kerja}

Hariandja (2006) mengemukakan bahwa, Rotasi kerja adalah proses perpindahan posisi dalam pekerjaan secara horizontal dengan tujuan mengatasi kejenuhan dalam bekerja, dan meningkatkan pengetahuan serta keahlian karyawan. Penelitian yang dilakukan Fatmawati (2012) dan Nur Aini (2015) menunjukkan bahwa rotasi kerja berpengaruh terhadap motivasi kerja. Berdasarkan uraian tersebut, dalam penelitian ini hipotesis dirumuskan sebagai berikut: H4: Ada pengaruh rotasi pegawai terhadap motivasi kerja.

\section{Pengaruh Motivasi Kerja terhadap Kinerja Pegawai}

Kinerja merupakan suatu fungsi dari motivasi dan kemampuan (Rivai, 2004). Manajer yang mempunyai motivasi berprestasi tinggi cenderung memiliki prestasi kerja yang tinggi, dan sebaliknya jika mereka yang prestasi kerjanya rendah dimungkinkan karena motivasi berprestasi yang rendah (Mangkunegara, 2004). Hasil penelitian Fatmawati (2012) dan Hormati (2016) menyimpulkan bahwa ada hubungan yang positif antara motivasi kerja dengan kinerja pegawai Berdasarkan uraian tersebut, dalam penelitian ini hipotesis dirumuskan sebagai berikut: H5: Ada pengaruh motivasi kerja terhadap kinerja pegawai 
Dari telaah pustaka dan hasil penelitian terdahulu maka model atau kerangka pemikiran penelitian dapat digambarkan sebagaimana gambar 1 di bawah ini:

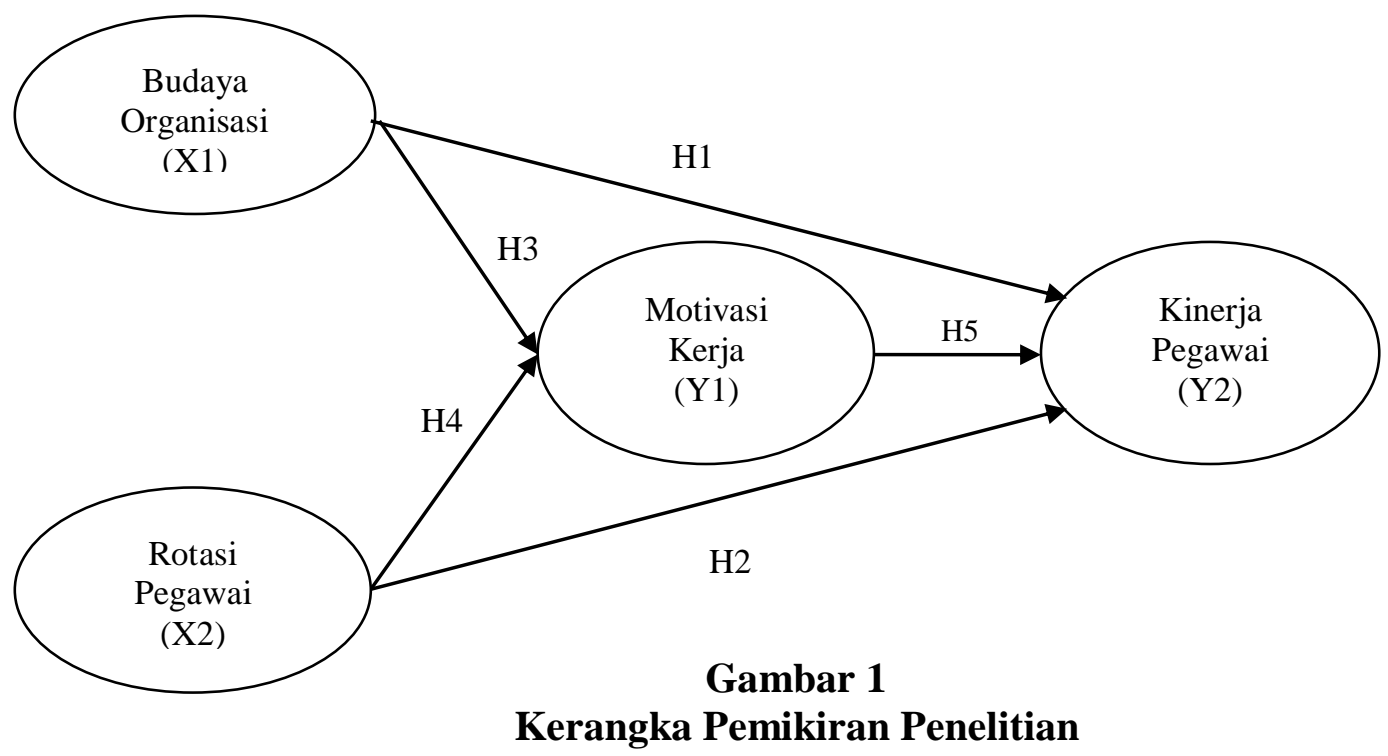

\section{METODE}

Jenis penelitian pada penelitian ini adalah penelitian eksplanatori. Adapun penelitian eksplanatori adalah penelitian yang menjelaskan hubungan kausal antara variabel-variabel yang mempengaruhi hipotesis. Pada penelitian ini minimal terdapat dua variabel yang dihubungkan dan penelitian ini berfungsi menjelaskan, meramalkan dan mengontrol suatu gejala. Oleh karena itu dalam penelitian ini nantinya akan dijelaskan mengenai adanya hubungan interaktif atau timbal balik antara variabel yang akan diteliti dan sejauh mana hubungan tersebut saling mempengaruhi.

Sumber data yang digunakan dalam penelitian ini adalah data primer. Data primer adalah data yang diperoleh langsung dari sumber asli (tanpa perantara). Data primer dalam penelitian ini diperoleh dari hasil penyebaran kuesioner pada sampel yang telah ditentukan, dalam hal ini pegawai pada KPPBC TMP Tanjung Emas. Merujuk pada pendapat Suharsimi Arikunto, jumlah sampel penelitian ini adalah 70 pegawai, dengan kriteria pegawai yang telah bekerja minimal selama 3 (tiga) tahun dan pernah mengalami rotasi.

Teknik Analisis Data Metode analisis yang digunakan dalam penelitian ini adalah analisis jalur. Analisis jalur ini bertujuan untuk memperoleh gambaran yang menyeluruh mengenai hubungan antara variabel independen dan variabel dependen untuk baik secara lanngsung maupun tak langsung melalui variabel intervening (mediasi).

Metode pengumpulan data yang digunakan dalam penelitian ini adalah metode survei. Metode survei yang digunakan adalah dengan cara menyebarkan kuesioner kepada responden dalam bentuk daftar pertanyaan yang disusun secara tertulis. Kuesioner ini bertujuan untuk memperoleh data yang berupa jawaban dari responden. Data kuesioner terdiri dari profil responden, beberapa bagian pertanyaan, masing-masing bagian terdapat beberapa item pertanyaan. Skala Likert merupakan metode yang mengukur sikap dengan menyatakan setuju atau ketidaksetujuannya terhadap subyek, obyek atau kejadian tertentu. Skala 1-5 maka variabel yang akan diteliti dan dijabarkan menjadi indikator variabel. Kemudian indikator itu menjadi 
titik tolak untuk menyusun item-item instrumen yang memakai skala likert pengukuran dan mempunyai gradasi dari sangat negatif sampai sangat positif.

Metode analisis data adalah suatu metode yang digunakan untuk mengolah hasil penelitian guna memperoleh suatu kesimpulan. Dengan melihat kerangka pemikiran teoritis, maka teknik analisis data yang digunakan dalam penelitian ini adalah analisis kuantitatif dengan menggunakan metode statistik dan data tersebut diklasifikasikan ke dalam ketegori tertentu dengan menggunakan tabel untuk mempermudah dalam menganalisa dengan alat bantu program komputer Statistical Package for Social Science (SPSS).

\section{HASIL DAN PEMBAHASAN}

Pada penelitian dengan menggunakan metode penyebaran kuesioner ini diperoleh jawaban kuesioner dari 70 responden, data yang diperoleh menunjukkan bahwa karakteristik responden adalah sebagai berikut : jenis kelamin didominasi laki-laki sebanyak 58 orang $(82,9 \%)$, umur responden didominasi umur 28-32 tahun sebanyak 29 orang (41,4\%), pendidikan terakhir D3 sebanyak 25 orang $(35,7 \%)$ dan masa kerja 3 - 7 tahun yaitu sebanyak $44,3 \%$ dari keseluruhan responden yang diteliti dalam penelitian ini.

Hasil analisis data dengan menggunakan analisis kuantitaif dengan menggunakan alat analisis Statistical Package for Social Science (SPSS), dapat dilihat dalam penjelasan dan tabel sebagai berikut: Uji Istrumen meliputi uji validitas dan uji reliabilitas. Hasil uji validas menunjukkan bahwa butir pernyataan kuesioner memenuhi kriteria validitas karena nilai $r$ hitung $>$ nilai $\mathrm{r}$ tabel $(0,235)$ sebagaimana terlihat pada tabel 1 di bawah dan hasil uji reliabilitas menunjukkan koefisien Cronbach's Alpha dari tiap variabel bernilai > 0,6 sehingga dapat dinyatakan reliabel.

\section{Tabel 1}

Hasil Uji Reliabilitas

\begin{tabular}{ccc}
\hline Variabel & Cronbach's Alpha & Keterangan \\
\hline Budaya Organisasi (X1) & 0,821 & Reliabel \\
\hline Rotasi Pegawai (X2) & 0,759 & Reliabel \\
\hline Motivasi Kerja (Y1) & 0,752 & Reliabel \\
\hline Kinerja Pegawai (Y2) & 0,788 & Reliabel \\
\hline
\end{tabular}

Sumber: Analisis Data Penelitian, 2020

Hasil uji asumsi klasik meliputi uji normalitas, uji multikolinearitas dan uji skedastisitas. Hsil uji normalitas dengan statistik non-parametrik Kolmogorov-Smirnov diperoleh nilai Asymp Sig bernilai > 0,05 maka residual berdistribusi normal, hasil uji multikolinearitas menunjukkan bahwa semua variabel bebas nilai Tolerance $>0,1$ dan VIF $<10$ sehingga dinyatakan tidak terjadi multikolinearitas pada model, dan hasil uji heteroskedastisitas dengan Glejser diperoleh nilai Sig. > 0,05 maka tidak ada gejala heteroskedastisitas pada variabel-variabel yang diukur. 
Hasil uji analisis jalur (Path Analysis) terlihat sebagaimana tabel 3 dan 4 di bawah ini:

Tabel 2

Hasil Analisis Jalur Model 1

Coefficients $^{\mathrm{a}}$

\begin{tabular}{cccccc}
\hline & \multicolumn{4}{c}{ Unstandardized Coefficients } & \multicolumn{2}{c}{ Standardized Coefficients } & \\
\cline { 2 - 5 } Model & B & Std. Error & Beta & Sig. \\
\hline (Constant) &,- 948 & 1,512 & $-, 627,533$ \\
Budaya Organisasi &, 488 &, 089 &, 603 & $5,457,000$ \\
Rotasi Pegawai &, 359 &, 128 &, 310 & $2,811,006$ \\
\hline
\end{tabular}

a. Dependent Variable: Motivasi Kerja

Sumber: Analisis Data Penelitian, 2020

Berdasarkan hasil analisis jalur model 1 diperoleh persamaan berikut:

$$
\begin{gathered}
\mathrm{Y} 1=\mathrm{b} 1 \mathrm{X} 1+\mathrm{b} 2 \mathrm{X} 2+\mathrm{e} \quad, \text { dimana } \mathrm{e}=\sqrt{1-\mathrm{R}^{2}}, \mathrm{R}^{2}=0,779(\text { Tabel } 7) \\
\mathrm{Y} 1=0,603 \mathrm{X} 1+0,310 \mathrm{X} 2+0,470
\end{gathered}
$$

Berdasarkan persamaan di atas, dapat diinterpretasikan bahwa budaya organisasi dan rotasi pegawai berpengaruh positif terhadap motivasi kerja. Hal ini menunjukkan bahwa semakin meningkat budaya organisasi dan rotasi pegawai, maka akan diikuti peningkatan pada motivasi kerja.

Tabel 3

Hasil Analisis Jalur Model 2

Coefficients $^{\mathrm{a}}$

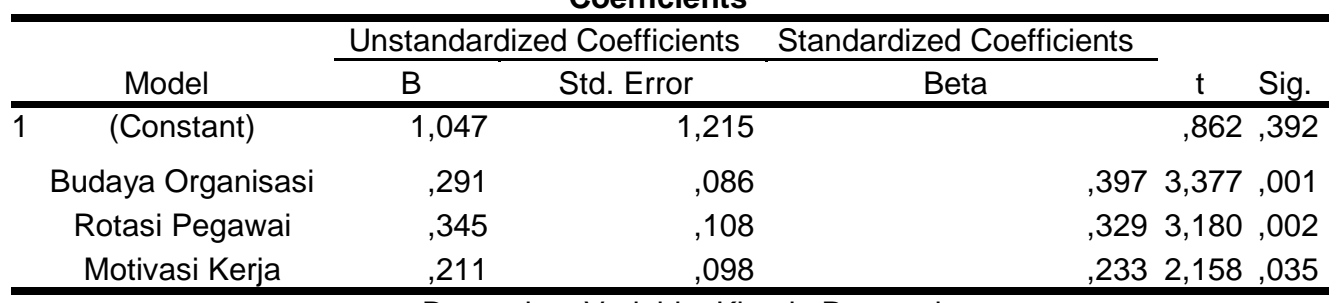

a. Dependent Variable: Kinerja Pegawai

Sumber: Analisis Data Penelitian, 2020

Berdasarkan hasil analisis jalur model 2 diperoleh persamaan berikut:

$$
\begin{gathered}
\mathrm{Y} 2=\mathrm{b} 3 \mathrm{X} 1+\mathrm{b} 4 \mathrm{X} 2+\mathrm{b} 5 \mathrm{Y} 1+\mathrm{e}, \text { dimana } \mathrm{e}=\sqrt{1-\mathrm{R}^{2}}, \mathrm{R}^{2}=0,829(\text { Tabel } 8) \\
\mathrm{Y} 2=0,397 \mathrm{X} 1+0,329 \mathrm{X} 2+0,233 \mathrm{Y} 1+0,414
\end{gathered}
$$

Berdasarkan persamaan di atas, dapat diinterpretasikan bahwa budaya organisasi, rotasi pegawai, dan motivasi kerja berpengaruh positif terhadap kinerja pegawai. Hal ini menunjukkan bahwa semakin meningkat budaya organisasi, rotasi pegawai, dan motivasi kerja maka akan diikuti peningkatan pada kinerja pegawai.

Dari hasil analisis jalur yang telah diuraikan di atas, dapat dijelaskan dengan gambar 2 di bawah ini: 


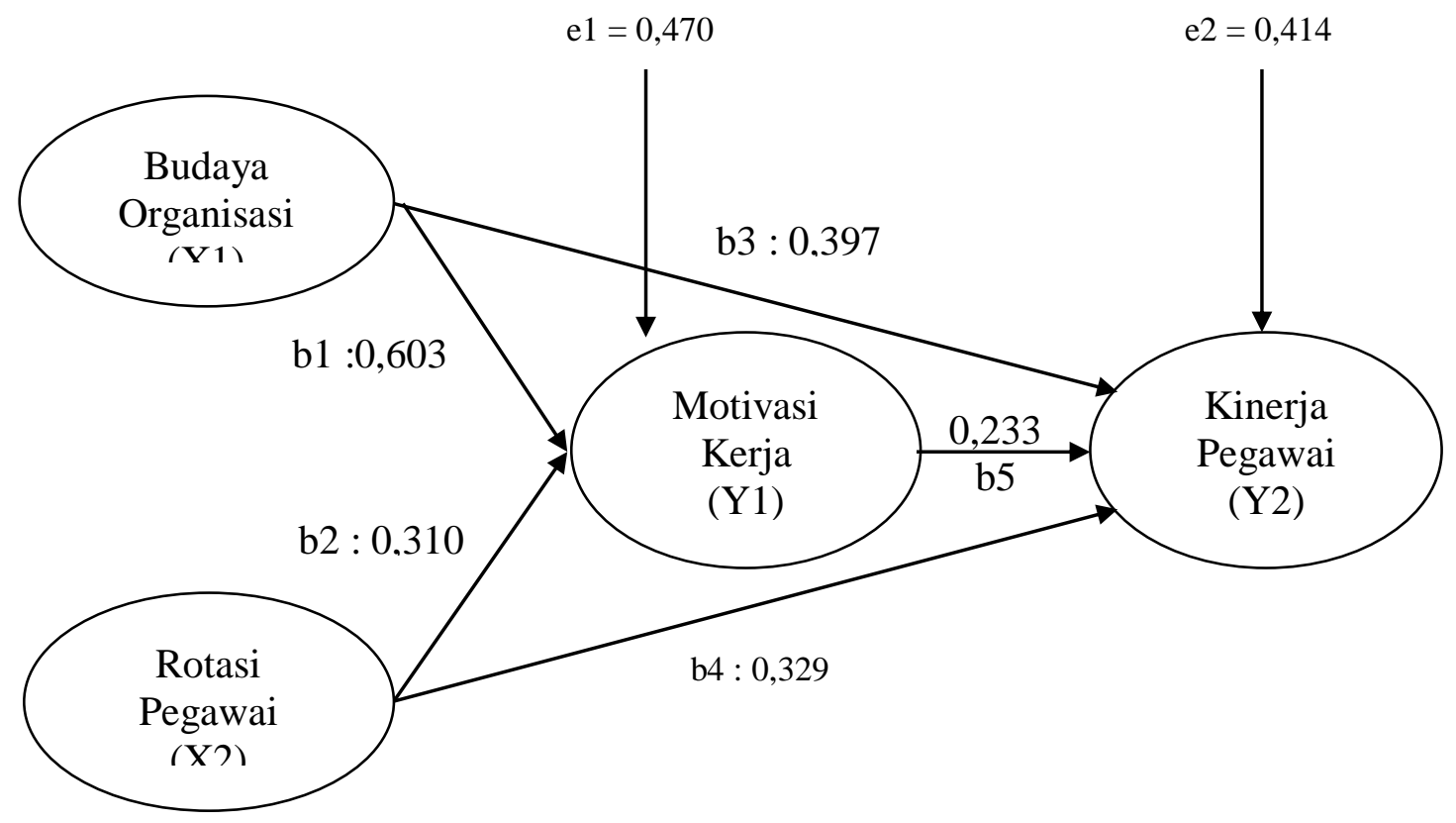

Gambar 2

Hasil Analisis Jalur

Hasil uji Goodness of Fit meliputi uji F dan uji determinasi. Hasil Uji F menunjukkan bahwa nilai signifikansi $0,000<0,05$ maka analisis jalur 1 layak untuk digunakan sebagaimana tabel 5 di bawah ini:

\section{Tabel 4}

\section{Hasil Uji F Model 1}

ANOVA $^{\text {b }}$

\begin{tabular}{crrrr}
\hline Model & Sum of Squares df & Mean Square & F & Sig. \\
\hline 1 Regression & 235,672 & 2 & 117,836 & $117,887,000^{\mathrm{a}}$ \\
Residual & 66,971 & 67 & 1,000 \\
Total & 302,64369 & \\
\hline a. Predictors: (Constant), Rotasi Pegawai, Budaya Organisasi
\end{tabular}

b. Dependent Variable: Motivasi Kerja

Sumber: Analisis Data Penelitian, 2020

Hasil Uji F menunjukkan bahwa nilai signifikansi $0,000<0,05$ maka analisis jalur 2 layak untuk digunakan sebagaimana tabel 6 di bawah ini:

Tabel 5

Hasil Uji F Model 2

ANOVA $^{\mathrm{b}}$

\begin{tabular}{crrrrr}
\hline Model & Sum of Squares & df & Mean Square & $F$ & Sig. \\
\hline 1 Regression & 205,900 & 3 & 68,633 & 106,871 &, $000^{\mathrm{a}}$ \\
Residual & 42,386 & 66 &, 642 & & \\
Total & 248,286 & 69 & & & \\
\hline
\end{tabular}

a. Predictors: (Constant), Motivasi Kerja, Rotasi Pegawai, Budaya Organisasi

b. Dependent Variable: Kinerja Pegawai

Sumber: Analisis Data Penelitian, 2020 
hasil Uji Determinasi menunjukkan seberapa jauh kemampuan model regresi dalam menjelaskan variansi variabel dependen (terikat) ditunjukkan oleh nilai $\mathrm{R}^{2}(R$ Square) sebagaimana terlihat pada tabel 7 dan 8 di bawah ini:

Tabel 6

Koefisien Determinasi Model 1

Model Summary

\begin{tabular}{cccccc}
\hline Model & $\mathrm{R}$ & $\mathrm{R}$ Square & $\begin{array}{c}\text { Adjusted R } \\
\text { Square }\end{array}$ & $\begin{array}{c}\text { Std. Error of the } \\
\text { Estimate }\end{array}$ \\
\hline 1 &, $882^{\mathrm{a}}$ &, 779 &, 772 & 1,000 \\
\hline a. Predictors: (Constant), Rotasi Pegawai, Budaya Organisasi
\end{tabular}

Sumber: Analisis Data Penelitian, 2020

nilai $\mathrm{R}^{2}$ ( $R$ Square) yaitu 0,779 sehingga dapat diketahui kemampuan regresi model 1 dalam menjelaskan variansi variabel dependen sebesar $0,779 \times 100 \%=77,9 \%$. Sisanya dijelaskan oleh variabel lain yang tidak diteliti dalam penelitian ini.

Tabel 7

Koefisien Determinasi Model 2 Model Summary

\begin{tabular}{|c|c|c|}
\hline Model & R Square & $\begin{array}{l}\text { Std. Error of the } \\
\text { Estimate }\end{array}$ \\
\hline 1 &, $911^{\mathrm{a}}$ & $\begin{array}{ll}, 822 & , 801\end{array}$ \\
\hline
\end{tabular}

Sumber: Analisis Data Penelitian, 2020

Koefisien determinasi model 2 ditunjukkan oleh nilai $\mathrm{R}^{2}$ ( $R$ Square) yaitu 0,829 sehingga dapat diketahui kemampuan regresi model 2 dalam menjelaskan variansi variabel dependen sebesar $0,829 \times 100 \%=82,9 \%$. Sisanya dijelaskan oleh variabel lain yang tidak diteliti dalam penelitian ini.

Hasil uji hipotesis (Uji t) menunjukkan nilai signifikansi $<0,05$ maka dinyatakan bahwa variabel bebas berpengaruh signifikan terhadap variabel terikat. Jika nilai signifikansi yang dihasilkan masing - masing variabel pada Uji $\mathrm{t}<0.05$ maka Ho ditolak dan Ha di terima begitu juga sebaliknya jika nilai signifikansi > 0.05 maka Ho diterima dan Ha ditolak. Hasil Uji t pada analisis jalur model 1 dan 2 adalah sebagaimana telihat pada tabel 9 di bawah ini:

Tabel 9

Hasil Uji t

\begin{tabular}{lccc}
\hline \multicolumn{1}{c}{ Uji t } & p-value & ketetapan & Keterangan \\
\hline $\begin{array}{l}\text { Pengaruh budaya organisasi } \\
\text { terhadap kinerja pegawai }\end{array}$ & 0,001 & $<0,05$ & H1 diterima \\
\hline $\begin{array}{l}\text { Pengaruh rotasi pegawai terhadap } \\
\text { kinerja pegawai }\end{array}$ & 0,002 & $<0,05$ & H2 diterima \\
\hline $\begin{array}{l}\text { Pengaruh budaya organisasi } \\
\text { terhadap motivasi kerja }\end{array}$ & 0,000 & $<0,05$ & H3 diterima \\
\hline $\begin{array}{l}\text { Pengaruh rotasi pegawai terhadap } \\
\text { motivasi kerja }\end{array}$ & 0,006 & $<0,05$ & H4 diterima \\
\hline $\begin{array}{l}\text { Pengaruh motivasi kerja terhadap } \\
\text { kinerja pegawai }\end{array}$ & 0,035 & $<0,05$ & H5 diterima \\
\hline
\end{tabular}

Sumber: Analisis Data Penelitian, 2020 
Hasil uji mediasi hubungan antara variabel budaya organisai, motivasi kerja dan kinerja pegawai dengan Sobel Test menunjukkan nilai z hitung sebesar 2,2434. Sedangkan nilai z tabel dengan tingkat kepercayaan $95 \%$ atau dengan tingkat signifikansi $5 \%$ diperoleh nilai $\mathrm{Z}$ tabel sebesar $\pm 1,96$. Nilai z hitung 2,2434 >1,96 z tabel maka motivasi kerja mampu memediasi hubungan antara budaya organisasi dan kinerja pegawai. Berdasarkan hasil pengujian tersebut di atas dapat dijabarkan pembahasan yang berkaitan dengan pengaruh masing-masing variabel bebas terhadap variabel terikat dan variabel mediasi sebagai berikut:

\section{Budaya Organisasi berpengaruh terhadap Kinerja Pegawai}

Hasil penelitian menunjukkan bahwa budaya organisasi berpengaruh positif dan signifikan terhadap kinerja pegawai. Pengaruh positif dan signifikan menunjukkan bahwa jika terjadi peningkatan pada budaya organisasi, maka akan diikuti peningkatan pada kinerja pegawai. Keberhasilan pelaksanaan budaya organisasi antara lain dapat dilihat dari peningkatan tanggung jawab, peningkatan kedisiplinan, kepatuhan pada norma atau aturan, terjadinya komunikasi dan hubungan yang harmonis dengan semua tingkatan, peningkatan partisipasi dan kepedulian, berkurangnya tingkat kemangkiran dan keluhan. Hasil penelitian ini sejalan dengan hasil penelitian Fatmawati (2012) dan Tharig (2014) yang menunjukkan adanya pengaruh budaya organisasi terhadap kinerja pegawai.

\section{Rotasi Pegawai berpengaruh terhadap Kinerja Pegawai}

Hasil penelitian menunjukkan bahwa rotasi pegawai berpengaruh positif dan signifikan terhadap kinerja pegawai. Pengaruh positif dan signifikan menunjukkan bahwa jika terjadi peningkatan pada rotasi pegawai, maka akan diikuti peningkatan pada kinerja pegawai. Rotasi kerja dimaksudkan untuk mengurangi kejenuhan, memberikan kesegaran kerja, serta menambah keterampilan dan pengalaman kepada karyawan. Hasil penelitian ini sejalan dengan hasil penelitian Fatmawati (2012) dan Nur Aini (2015) yang menunjukkan adanya pengaruh rotasi pegawai terhadap kinerja pegawai.

\section{Budaya Organisasi berpengaruh terhadap Motivasi Kerja}

Hasil penelitian menunjukkan bahwa budaya organisasi berpengaruh positif dan signifikan terhadap motivasi kerja. Pengaruh positif dan signifikan menunjukkan bahwa jika terjadi peningkatan pada budaya organisasi, maka akan diikuti peningkatan pada motivasi kerja. Keberhasilan pelaksanaan budaya organisasi antara lain dapat dilihat dari peningkatan tanggung jawab, peningkatan kedisiplinan, kepatuhan pada norma atau aturan, terjadinya komunikasi dan hubungan yang harmonis dengan semua tingkatan, peningkatan partisipasi dan kepedulian, berkurangnya tingkat kemangkiran dan keluhan. Hasil penelitian ini sejalan dengan hasil penelitian Fatmawati (2012) dan Hormati (2016) yang menunjukkan adanya pengaruh budaya organisasi terhadap motivasi kerja.

\section{Rotasi Pegawai berpengaruh terhadap Motivasi Kerja}

Hasil penelitian menunjukkan bahwa rotasi pegawai berpengaruh positif dan signifikan terhadap motivasi kerja. Pengaruh positif dan signifikan menunjukkan bahwa jika terjadi peningkatan pada rotasi pegawai, maka akan diikuti peningkatan pada motivasi kerja. Motivasi kerja pada pegawai juga dapat dipengaruhi oleh adanya rotasi pekerjaan. Rotasi pekerjaan mendorong adanya penambahan kemampuan dan perilaku dari pegawai lama serta untuk orientasi dan penempatan pegawai baru, mengurangi kejenuhan, memberikan kesegaran kerja, serta menambah keterampilan dan pengalaman kepada karyawan sehingga karyawan menjadi lebih termotivasi dalam bekerja. Apabila ada karyawan yang cuti atau tidak masuk kerja, tugas dan pekerjaan karyawan yang bersangkutan dapat dilaksanakan oleh karyawan lain. Hasil 
penelitian ini sejalan dengan hasil penelitian Fatmawati (2012) dan Hormati (2016) yang menunjukkan adanya pengaruh rotasi pegawai terhadap motivasi kerja.

\section{Motivasi Kerja berpengaruh terhadap Kinerja Pegawai}

Hasil penelitian menunjukkan bahwa motivasi kerja berpengaruh positif dan signifikan terhadap kinerja pegawai. Pengaruh positif dan signifikan menunjukkan bahwa jika terjadi peningkatan pada motivasi kerja, maka akan diikuti peningkatan pada kinerja pegawai. Motivasi perlu dilakukan pemimpin kepada bawahannya, karena pemimpin membagi pekerjaan kepada bawahannya untuk dikerjakan dengan baik, ada bawahan yang mampu untuk mengerjakan pekerjaannya, tetapi yang bersangkutan malas mengerjakannya. Untuk memelihara atau meningkatkan kegairahan kerja bawahan dan menyelesaikan tugas-tugasnya untuk memberikan penghargaan kerja kepada bawahannya. Pemberian motivasi harus diarahkan dengan baik menurut prioritas dan dapat diterima dengan baik oleh karyawan, karena motivasi tidak dapat diberikan untuk setiap karyawan dengan bentuk yang sama. Hasil penelitian ini sejalan dengan hasil penelitian Fatmawati (2012) dan Hormati (2016) yang menunjukkan adanya pengaruh motivasi kerja terhadap kinerja pegawai.

\section{PENUTUP}

Berdasarkan hasil analisis dan interpretasi bab sebelumnya, maka dapat disimpulkan bahwa untuk meningkatkan kinerja pegawai pada KPPBC TMP Tanjung Emas dapat dilakukan dengan meningkatkan budaya organisasi, rotasi pegawai, dan motivasi kerja. Budaya organisasi berpengaruh positif dan signifikan terhadap kinerja pegawai, semakin baik budaya organisasi maka dapat meningkatkan kinerja pegawai. Rotasi pegawai berpengaruh positif dan signifikan terhadap kinerja pegawai, semakin meningkat rotasi pegawai maka dapat meningkatkan kinerja pegawai. Budaya organisasi berpengaruh positif dan signifikan terhadap motivasi kerja, semakin baik budaya organisasi maka dapat meningkatkan motivasi kerja. Rotasi pegawai berpengaruh positif dan signifikan terhadap motivasi kerja, semakin meningkat rotasi pegawai akan meningkatkan motivasi kerja. Motivasi kerja berpengaruh positif dan signifikan terhadap kinerja pegawai, semakin meningkat motivasi kerja pegawai maka akan meningkatkan kinerja pegawai.

Berdasarkan hasil analisis dan interpretasi bab sebelumnya, maka dapat diambil implikasi kebijakan. Budaya organisasi berpengaruh positif dan signifikan terhadap kinerja pegawai maka dari itu manajemen hendaknya menginternalisasikan dan mengembagkan budaya organisasi kepada pegawai melalui Program Pembinaan Keterampilan Pegawai (PPKP), kegiatan lomba inovasi pegawai, dan familiy gathering untuk membangun kerja sama dan kebersamaan diantara pegawai. Rotasi pegawai berpengaruh positif dan signifikan terhadap kinerja pegawai, hendaknya manajemen memberikan coaching and counseling kepada para pegawai dan mengusulkan pegawai untuk diklat. Budaya organisasi berpengaruh positif dan signifikan terhadap motivasi kerja maka manajemen hendaknya menciptakan suasana kantor yang homy dengan penataan lay out kantor dan ketersediaan sarana dan prasarana yang baik dengan memperhatikan kebutuhan pegawai. Rotasi pegawai berpengaruh positif dan signifikan terhadap motivasi kerja maka manajemen hendaknya memberikan penghargaan kepada pegawai yang berprestasi dan kesempatan bagi pegawai untuk mengikuti pelatihan atau seminar. Motivasi kerja berpengaruh positif dan signifikan terhadap kinerja pegawai maka manajemen hendaknya memotivasi pegawai dengan memberikan penghargaan kepada pegawai dengan pemilihan employee of the month, meningkatkan fasilitas kesehatan dasar dengan ketersediaan obat-obatan, perawat dan dokter di klinik kesehatan kantor dan mengadakan kegiatan bimbingan mental secara umum dan khusus sesuai dengan agama masing-masing pegawai.

Berdasarkan simpulan penelitian di atas, penelitian ini memiliki beberapa keterbatasan antara lain penulis tidak dapat menjelaskan kepada setiap responden maksud dari tiap-tiap butir 
pernyataan atau pernyataan yang ada dalam kuesioner, sehingga jawaban responden sangat bergantung pada persepsi masing-masing dan penelitian ini hanya memberikan gambaran mengenai pengaruh budaya organisasi, rotasi pegawai, dan motivasi kerja terhadap kinerja pegawai pada KPPBC TMP Tanjung Emas, sehingga hasil penelitian hendaknya tidak digunakan untuk generalisasi.

\section{DAFTAR PUSTAKA}

Bangun, Wilson. (2012). Manajemen Sumber Daya Manusia. Jakarta: Erlangga.

Busro, Muhammad. (2018). Teori-teori Manajemen Sumber Daya Manusia. Jakarta : Prenadamedia Group.

Cahyono, Tri Bambang. 2010. Manajemen Sumber Daya Manusia. Jakarta: IPWI.

Daft, Richard L. 2006. Manajemen, Edisi 6. Jakarta: Salemba Empat.

Dhermawan, Anak Agung Ngurah Bagus, I Gde Adnyana Sudibya, I Wayan Mudiartha Utama. (2012). Pengaruh Motivasi, Lingkungan Kerja, Kompetensi, dan Kompensasi Terhadap Kepuasan Kerja dan Kinerja Pegawai di Lingkungan Kantor Dinas Pekerjaan Umum Provinsi Bali. Jurnal Manajemen, Strategi Bisnis, dan Kewirausahaan Vol. 6, No. 2.

Djarwanto dan Pangestu Subagyo. (2002). Statistik Induktif. Edisi ke-empat. Cetakan Keempat. BPFE.

Fatmawati, Mahdani, dan Sofyan Idris. (2012). Pengaruh Budaya Organisasi Dan Rotasi Pekerjaan Terhadap Motivasi Kerja Serta Implikasinya Pada Kinerja Pegawai Iain ArRaniry Banda Aceh. Jurnal Manajemen Pascasarjana Universitas Syiah Kuala. Vol. 1 (1): 25- 40.

Ferdinand, Augusty. (2006), “Metode Penelitian Manajemen”, Pedoman Penelitian Untuk Penulisan Skripsi, Tesis dan Disertasi Ilmu Manajemen, Semarang: Badan Penerbit Universitas Diponegoro.

Ghozali, Imam. (2011). Aplikasi Analisis Multivariate Dengan Program SPSS. Semarang: Badan Penerbit Universitas Diponegoro.

Handoko, T. Hani. (2000). Manajemen Personalia dan Sumber Daya Manusia. Yogyakarta: BPFE.

Hariandja, Marihot Tua Efendi. (2006). Perilaku Organisasi. Bandung: Unpar Press.

Hasibuan, Malayu S.P. (2011). Manajemen: Dasar, Pengertian, dan Masalah. Jakarta: PT Aksara.

Hasibuan, Malayu. (2014). Manajemen Sumber Daya Manusia. Edisi Revisi. Jakarta: PT Bumi Aksara 
Hormati, Theolina. (2016). Pengaruh Budaya Organisasi, Rotasi Pekerjaan Terhadap Motivasi Kerja dan Kinerja Pegawai (Studi Pada Tenaga Medis Perawat di RSUD Sele Be Solu Kota Sorong Provinsi Papua Barat). Jurnal EMBA Vol.4 No.2: 298-410.

Husein Umar. (2007). Metode Penelitian Untuk Skripsi Dan Tesis Bisnis. Jakarta: PT. Raja Grafindo Persada.

Ismail Solihin. (2006). Manajemen Strategik. Jakarta: Erlangga

Kadarisman, M. (2014). Manajemen Pengembangan Sumber Daya. Manusia. Jakarta: Rajawali Pers.

Kreitner, Robert dan Angelo Kinicki. 2014. Organizational Behavioral - Ed. 5. Boston: McGraw-Hill.

Mangkunegara, A. Anwar Prabu. (2009). Evaluasi Kinerja Sumber Daya Manusia. Bandung: Penerbit Refika Aditama.

Mangkunegara, A. Anwar Prabu. (2011). Manajemen Sumber Daya Manusia. Bandung: PT. Remaja Rosdakarya.

Mathis, Robert L dan Jackson. (2011). Manajemen Sumber Daya Manusia. Edisi 9. Jakarta: Salemba Empat.

McShane, Steven L dan Von Glinow, Mary A. (2010). Organizational Behaviour-Emerging Knowledge and Practice For The Real World $5^{\text {th }}$ Edition. New York: McGraw-Hill.

Megantara, Ilma, Suliyanto, Ratno Purnomo. (2019). Pengaruh Budaya Organisasi Dan Rotasi Pekerjaan Terhadap Motivasi Kerja Untuk Meningkatkan Kinerja Pegawai. Jurnal Ekonomi, Bisnis, dan Akuntansi (JEBA) Volume 21 Nomor 01.

Mourdoukoutas, Panos. (1994) Job Rotation and Public Policy : Theory with Applications to Japan and The USA. International Journal of Manpower, Vol.15.

Nila Tania. (2014). Pengaruh Budaya Organisasi Terhadap Motivasi Kerja Karyawan Studi Kasus di Pondok Pesantren Moderen Islam Assalam Kota Surakarta. Artikel Publikasi Universitas Muhammadiyah Surakarta.

Novita. (2011). Faktor - faktor yang mempengaruhi Motivasi Kerja. Jakarta: PT. Gunung Agung.

Nur Aini dan Tulus. (2015). Analisis Pengaruh Rotasi dan Mutasi Kerja Terhadap Kinerja Karyawan di KJKS BMT Anda Salatiga. Jurnal Muqtasid, Volume 6, Nomor 1.

Nurdin, Ismail dan Hartati, Sri. (2009). Metodologi Penelitian Sosial. Surabaya : Penerbit Media Sahabat Cendikia.

Ojo, Olu. (2009). Impact Assessment Of Corporate Culture On Employee Job Performance. Business Intelligence Journal. Vol. 2 No. 2, pg. 488-497. 
Pabundu Tika. (2010). Budaya Organisasi dan Peningkatan Kinerja Perusahaan, cetakan ke-4. Jakarta : PT. Bumi Aksara.

Rivai, Veithzal. (2011). Manajemen Sumber Daya Manusia Untuk Perusahaan, Cetakan Pertama. Jakarta: PT. Raja GrafindoPersada.

Rivai. (2004). Penilaian Prestasi Kerja Teori dan Praktek. Jakarta. PT. Ganudra Pustaka Utama.

Robbins, Stephen. P. and Judge, Timothy A. (2015). Perilaku Organisasi Edisi 16 (alih bahasa Ratnasaraswati dan Febriella Sirait), Edisi Bahasa Indonesia, Jakarta: Penerbit Salemba Empat.

Santoso Singgih. (2002). Statistik Parametrik, Cetakan Ketiga, PT Gramedia Pustaka. Utama, Jakarta.

Santoso. (2017). Pengaruh Rotasi Pegawai, Kepuasan Kerja dan Perilaku Kerja Terhadap Kinerja Pegawai Negeri Sipil di Lingkungan Balai Pendidikan dan Pelatihan Transportasi Darat Palembang. Jurnal Media Wahana Ekonomika, Vol. 14, No. 4: 61-68

Saydam, Gouzali. (2005). Manajemen Sumber daya Manusia: Suatu Pendekatan Mikro. Jakarta: Djambaran.

Schermerhorn, John D., James G. Hunt \& Richard N. Osborn. (2009). Organizational Behavior. New York: John Willey and Son Inc.

Sembiring, Masana. (2012). Budaya dan Kinerja Organisasi. Bandung: Fokusmedia.

Soedjono. (2005). Pengaruh Budaya Organisasi Terhadap Kinerja Organisasi dan Kepuasan Kerja Karyawan pada Terminal Penumpang Umum di Surabaya. Jurnal Manajemen dan Kewirausahaan Vol. 7 No. 1. STIESIA Surabaya.

Srimulyo, E. (2010). Penilaian Kinerja dan Imbalan: Suatu Alternatif Keluar dari Krisis. Jakarta: PT. Raja Grafindo Pustaka.

Sugiyono. (2016). Metode Penelitian Kuantitatif, Kualitatif dan R\&D. Bandung: PT Alfabeta.

Suharsimi, Arikunto. (2005). Manajemen Penelitian. Jakarta : Rineka Cipta.

Sunarto. (2005). Manajemen Sumber Daya Manusia Strategik. Yogyakarta: Amus.

Supranto, M.A. (2002). Metode Peramalan Kuantitatif untuk Perencanaan Ekonomi dan Bisnis. Jakarta : Rineka Cipta.

Sutrisno, Edi. (2009). Manajemen Sumber Daya Manusia. Edisi Pertama. Jakarta: Kencana Prenada Media Group.

Tharig Kemal dan Kasmiruddin. (2014). Budaya Organisasi, Rotasi Pekerjaan, Dan Kinerja Pegawai. Jurnal Administrasi Pembangunan, Volume 2, Nomor 4, hlm. 227-460. 
Uno, Hamzah B. (2012). Teori Motivasi dan Pengukurannya. Jakarta: PT. Bumi. Aksara. Wahyudi, Bambang. (2002). Manajemen Sumber Daya Manusia. Jakarta: Sulita.

Wibowo. (2011). Budaya Organisasi:Sebuah Kebutuhan untuk Meningkatkan Kinerja Jangka Panjang. Jakarta: Rajawali Pers.

Wibowo. (2015). Manajemen Kinerja. Jakarta: PT. Raja Grafindo Persada

Wirawan. (2009). Evaluasi Kinerja Sumber Daya Manusia Teori Aplikasi dan Penelitian. Jakarta. Penerbit: Salemba Empat.

Wirawan. (2010). Konflik dan Manajemen Konflik. Teori, Aplikasi, dan Penelitian. Jakarta: Salemba Humanika. 